\title{
Systematic review and meta-analysis of ropivacaine use in laparoscopic hysterectomy
}

\section{Laparoskopik histerektomide ropivakain kullanımının sistematik derlemesi ve meta analizi}

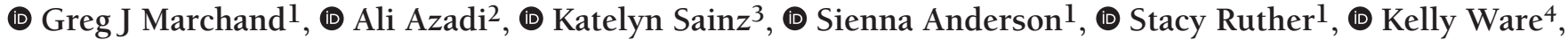

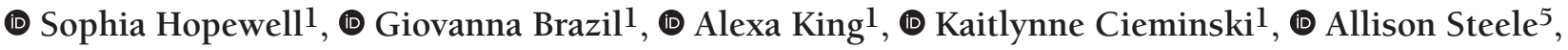 \\ (1) Jennifer Love ${ }^{5}$
}

${ }^{1}$ Marchand Institute for Minimally Invasive Surgery, Mesa, Arizona, USA

2Star Urogynecology, Peoria, Arizona, USA

${ }^{3}$ Washington University of Health and Science, San Pedro, Belize

${ }^{4}$ International University of Health Sciences, Basseterre, St. Kitts

5 Midwestern University Faculty of Medicine, Glendale, Arizona, USA

\begin{abstract}
To assess the efficacy of all forms of ropivacaine administration for the management of pain and opioid use, specifically in patients undergoing laparoscopic hysterectomy. We searched PubMed, Cochrane CENTRAL, Web of Science, and SCOPUS for relevant clinical trials matching our eligibility criteria. Outcomes of interest included: Pain intensity (measured either by visual analog scale score or by numerical rating scale score), QoR-40 score (Overall quality of recovery tool, designed to measure physical comfort, physical independence, pain, emotional status, and need for support), and the need for opioid rescue. We performed the analysis under the fixed-effects model for homogeneous data and random-effects model for heterogeneous data. Most heterogeneous data were solved by the leave-one-out method, in cases where this was not successful, we then proceeded to conduct at least one subgroup meta-analysis in an attempt to solve heterogeneity. We assessed the risk of bias using Cochrane's risk of bias tool. A total of five clinical trials were included. Regarding the pain score, there was no significant difference between either group [standardized mean difference=-0.17, 95\% confidence interval (CI): $(-0.56,0.23) ; \mathrm{p}=0.41]$. The analysis of the overall RoQ40 scores favored the ropivacaine group over the control group significantly [mean difference $(\mathrm{MD})=17.68,95 \% \mathrm{CI}:(1.48,33.87)$; $\mathrm{p}<0.001]$. Regarding the use of opioids, the analysis revealed no significant difference between either group [MD=$2.57,95 \%$ CI: $(-6.62,1.49) ; \mathrm{p}=0.21]$.

Ropivacaine administration by any method does not seem to be effective in reducing pain or reducing the need for opioid use after laparoscopic hysterectomy procedures; however, the administration did show a significant improvement in the patient's "overall quality of recovery," as measured using the QoR-40 tool.
\end{abstract}

Keywords: Laparoscopy, ropivacaine, hysterectomy, ERAS, MIGS

Öz

Özellikle laparoskopik histerektomi geçiren hastalarda ağrı ve opioid kullanımının yönetimi için tüm ropivakain formlarının etkinliğini değerlendirmek. Uygunluk kriterlerimizle eşleşen ilgili klinik araştırmalar için PubMed, Cochrane CENTRAL, Web of Science ve SCOPUS’u taradık. Aradığımız sonlanımlar şunlardı: Ağrı yoğunluğu (vizuel analog skala skoru veya sayısal değerlendirme ölçeği skoru ile ölçülen), QoR-40 skoru (fiziksel rahatlık, fiziksel bağımsızlık, ağrı, duygusal durum ve destek ihtiyacını ölçmek için tasarlanmış genel iyileşme kalitesi aracı) ve opioid ihtiyacı. Analizi homojen veriler için sabit etkiler modeli ve heterojen veriler için rastgele etkiler modeli altında gerçekleştirdik. Cochrane'nin bias riski aracını kullanarak bias riskini değerlendirdik. Toplam beş klinik çalışma dahil edildi. Ağrı skoru açısından her iki grup arasında anlamlı bir fark yoktu [standartlaştırılmış ortalama fark=-0,17 (\%95 güven aralığı $(\mathrm{GA})=-0,56,0,23) ; \mathrm{p}=0,41]$. Genel RoQ40 skorunun analizi, kontrol grubuna klyasla ropivakain grubu lehine sonuçlandı [ortalama fark (MD)=17,68 (\%95 GA=1,48, 33,87); $\mathrm{p}=0,001]$. Opioid kullanımı açısından her iki grup arasında anlamlı bir fark yoktu [MD=-2,57 (\%95 GA=-6,62, 1,49); $\mathrm{p}=0,21]$. Herhangi bir yöntemle ropivakain uygulaması ağrıı azaltmada veya laparoskopik histerektomi prosedürlerinden sonra opioid kullanımına olan ihtiyacı azaltmada etkili görünmemektedir; bununla birlikte ropivakain uygulaması, QoR-40 aracı ile ölçülen hastanın "genel iyileşme kalitesinde" önemli bir düzelme göstermiștir.

Anahtar Kelimeler: Laparoskopi, ropivakain, histerektomi, ERAS, MIGS

Address for Correspondence/Yazışma Adresi: Greg J Marchand MD,

Marchand Institute for Minimally Invasive Surgery, Mesa, Arizona, USA

Phone: +1 4806280566 E-mail: gm@marchandinstitute.org ORCID ID: orcid.org/0000-0003-4724-9148

Received/Geliș Tarihi: 03.10.2020 Accepted/Kabul Tarihi: 10.01.2021

${ }^{\circledR}$ Copyright 2021 by Turkish Society of Obstetrics and Gynecology

Turkish Journal of Obstetrics and Gynecology published by Galenos Publishing House. 


\section{Introduction}

Hysterectomy is the most common gynecologic surgical procedure undergone by women in the United States, with over 600,000 performed annually ${ }^{(1)}$. In gynecologic surgery, we have seen a persistent increase in the rate of hysterectomies performed via laparoscopic techniques over time ${ }^{(2,3)}$. About $30 \%$ of hysterectomies are performed using minimally invasive laparoscopic techniques( ${ }^{(4)}$. Laparoscopic surgeries have many benefits over abdominal approaches: they ensure faster recovery, fewer complications, less pain, and shorter hospital stay ${ }^{(5)}$. Many trials have been conducted to develop strategies to facilitate laparoscopic hysterectomy as an outpatient procedure when feasible ${ }^{(6)}$. However, pain control is still a major problem in postoperative care. Obtaining adequate postoperative analgesia can increase the advantages of the laparoscopic approach over abdominal surgery, and at least in theory, a painless recovery from laparoscopic surgery is possible. For this reason, many trials have been performed to find the best strategies to relieve pain after laparoscopic surgery ${ }^{(7)}$.

Patients undergoing laparoscopic hysterectomy have substantial pain and may require a large dose of opioids in the first 24 hours after the procedure ${ }^{(8)}$. Administration of opioids has many adverse effects such as nausea, vomiting, constipation, and respiratory depression ${ }^{(9)}$. The opioid-related adverse effects may impair the postoperative quality of recovery of patients undergoing this procedure. Administration of local analgesics either intraperitoneally or through the transversus abdominis plane (TAP) may reduce the total need for opioids in the first $24 \mathrm{~h}$ postoperatively ${ }^{(10)}$.

Ropivacaine is a long-acting amino amide local anesthetic agent with a duration of action that may extend to 8 hours ${ }^{(11)}$. Ropivacaine is commonly used for nerve block and intraperitoneal use. It produces its analgesic effect via reversible inhibition of sodium ion influx in nerve fibers ${ }^{(12)}$. Ropivacaine is less lipophilic than other local analgesic agents and less likely to penetrate large myelinated motor fibers, resulting in a relatively reduced motor blockade. The reduced lipophilicity is associated with less undesirable central nervous system toxicity and cardiotoxicity. For this reason, it is suitable for immediate pain control after uterine surgeries ${ }^{(13,14)}$.

TAP block is widely used as a pain management approach after various abdominal surgical procedures ${ }^{(15,16)}$. The TAP block consists of an injection of a local anesthetic agent between the internal oblique abdominal muscle and the transverse abdominal muscle ${ }^{(17)}$. This procedure interrupts the sensory innervation to the anterior abdominal wall and peritoneum ${ }^{(18)}$. Some trials have shown that TAP blocks lead to a significant reduction in narcotic consumption and recovery times in both open and laparoscopic surgery ${ }^{(19)}$.

In our meta-analysis, we aimed to estimate the effect of ropivacaine infiltration in the reduction of postoperative pain and the total need for opioids in the first $24 \mathrm{~h}$ postoperatively. This systematic review and meta-analysis were performed with strict adherence to the Preferred Reporting Items for Systematic Reviews and Meta-analyses (PRISMA) Statement ${ }^{(20)}$. In addition, we followed the guidelines reported in the Cochrane Handbook for Systematic Reviews of Interventions ${ }^{(21)}$.

\section{Literature Search}

We searched for published studies in four online databases: PubMed, Web of Science, Scopus, and Cochrane Central Register of Controlled Trials (CENTRAL) in August 2020. Our search was performed using the following keywords: ropivacaine, naropin, laparoscop*, and hysterectom* and combining these words with "AND" or "OR" as was necessary according to the search engine being used.

\section{Eligibility Criteria}

For eligibility, we included all studies that met all of the following criteria: (1) Patients: women undergoing laparoscopic hysterectomy, (2) Intervention: ropivacaine, (3) Comparator: placebo, (4) Outcomes: pain intensity [measured either using visual analog scale (VAS) scores or numerical rating scale (NRS) scores], overall quality of recovery (QoR-40 score), which is measured by physical comfort, physical independence, pain, emotional status, and support, and the need for opioid rescue. Type of Study: we only included randomized clinical trials (RCTs). Studies with other criteria were excluded, including (1) non-RCTs, (2) single-armed trials or with different comparators, (3) trials involving animals, and (4) studies for which there was no availability of a full-text copy of the paper.

\section{Screening and Studies Selection}

Our next step was to export the search results from our databases into Endnote X8.0.1 (Build 1044) and perform automatic removal of any duplicates. Following this, we screened the search results manually in two steps: first, we performed title and abstract screening, then we went on to perform full-text screening for the preliminary studies included in the first step. We included articles based on our criteria for eligibility and removed studies that did not fulfill these criteria.

\section{Data Extraction and Analysis}

After the screening step, we extracted data from the eligible studies. Data extracted were categorized into two main groups: (1) Demographic and baseline data of patients in each study including age, body mass index (BMI), sample size, dose of intervention, surgery time, blood lose, number of patients diagnosed by fibroid, number of patients diagnosed with endometriosis, number of patients diagnosed with prolapse, number of patients diagnosed with chronic pelvic pain. (2) Data for analysis include pain intensity (by VAS or NRS score), quality of recovery (QoR-40) score that includes physical comfort, physical independence, emotional status, pain RoQ40, and support. Additional outcomes included anti-emetic use and need for opioids. Data for continuous outcomes were extracted as a mean and standard deviation, and data for dichotomous outcomes were extracted as events and total. 


\section{Data Analysis}

We performed this analysis using the Review Manager software (RevMan 5.3). Data for continuous outcomes are expressed using mean difference (MD) and standard deviations, and dichotomous outcomes are expressed using percentage and total relative to a fixed $95 \%$ confidence interval (CI). We used standardized mean difference (SMD) whenever outcomes were measured using different scores. Heterogeneity was assessed using a statistical $\mathrm{I}^{2}$ test and $\mathrm{p}$-value of the chi-square test, where outcomes with $\mathrm{I}^{2}>50 \%, \mathrm{p}<0.1$ were considered heterogeneous, and outcomes with $\mathrm{I}^{2}<50 \%$, p $>0.1$ were considered homogeneous. Next, homogenous data were analyzed using a fixed-effects model, and the heterogeneous outcomes were analyzed using the random-effects model. In heterogeneous data not solved using the leave-one-out method, we then conducted a subgroup meta-analysis as the next step in attempting to solving heterogeneity.

\section{Quality Assessment}

We performed a quality assessment by an evaluation which used the GRADE Guidelines (Grading of Recommendations Assessment, Development and Evaluation). For our risk of bias (ROB) assessment, we used the Cochrane ROB tool for use in clinical trials $^{(22)}$. The Cochrane ROB assessment tool includes the following domains: random sequence generation (selection bias), allocation sequence concealment (selection bias), blinding of participants and personnel (performance bias), blinding of outcome assessment (detection bias), incomplete outcome data (attrition bias), selective outcome reporting (reporting bias) and other potential sources of bias. The authors' judgment is categorized as "Low risk", "High risk" or "Unclear risk" of bias.

\section{Results of Literature Search}

Out of 144 studies included through our literature search and references, only nine studies were eligible and included in the full-text literature. Five studies fulfilled our eligibility criteria after full-text screening and were included in our meta-analysis. Figure 1 illustrates the PRISMA statement of our literature search.

Three hundred eight patients were included (166 in the ropivacaine group, and 142 in the control group). The mean age of patients in the study group was $50.2 \pm 10.9$ years, and the mean age of the control group was $51.2 \pm 12.8$ years. The mean BMIs in the intervention group and the control group were $26.7 \pm 5.8$ and $27 \pm 5.3 \mathrm{~kg} / \mathrm{m}^{2}$, respectively. Detailed baseline characteristics for the included studies are shown in Table 1. The mean duration of surgery in the ropivacaine group and control group were 147.3 and 138.8 minutes respectively, and the mean blood loss was 92.5 and $72.5 \mathrm{~mL}$, respectively. Table 2 summarizes the surgical duration and blood loss in each study.

\section{Results of Quality Assessment}

The overall ROB of included studies was of low risk according to the Cochrane ROB assessment tool. All studies were at low risk regarding random sequence generation (selection bias) and allocation concealment. Three studies ${ }^{(23-25)}$ performed proper blinding of personnel and participants and therefore were considered as low risk, whereas the other two studies ${ }^{(26,27)}$ were at high risk of performance bias. Outcome assessors were blinded in De Oliveira et al., $2011^{(23)}$ and Torup et al. ${ }^{(25)} 2015$ and considered at low risk of detection bias. Three studies did not report whether outcome assessors were blinded and therefore were considered to have unclear risk of detection bias $^{(24,26,27)}$. All studies were of low ROB regarding attrition bias and reporting bias. No other ROB was detected in any study. Figure 2 illustrates the ROB of included studies.

\section{Results of Outcomes}

\section{Pain Score}

All included studies reported pain score outcomes. Three studies reported pain score outcomes using VAS scores ${ }^{(25-27)}$, whereas the others used NRS scores ${ }^{(23,24)}$. Therefore, we used the SMD. The analysis showed no significant difference between the ropivacaine and placebo groups [SMD=-0.17, 95\% CI: $(-0.56,0.23) ; p=0.41]$ (Figure 3A). Data were heterogeneous $\left(\mathrm{p}=0.007, \mathrm{I}^{2}=69 \%\right)$. In an attempt to solve the heterogeneity, we excluded one study ${ }^{(23)}(0.50 \% \mathrm{mg})$ from the analysis. Pooled analysis did not favor any one group over any other [SMD=0.00, 95\% CI: $(-0.30,0.30) ; \mathrm{p}=0.99]$. Data were homogeneous $\left(\mathrm{p}=.17, \mathrm{I}^{2}=38 \%\right)$. Figure $3 \mathrm{~B}$ shows the analysis of pain score outcomes after the leave-one-out method.

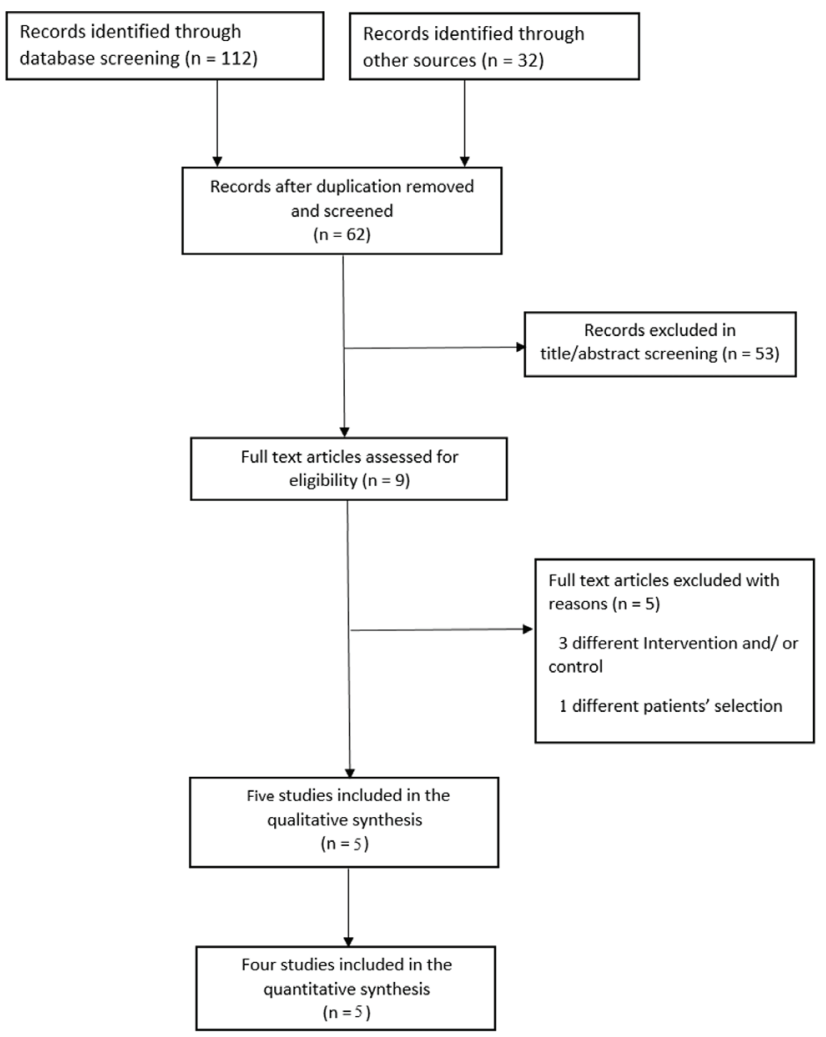

Figure 1. PRISMA flowchart diagram 


\section{QoR-40 Score}

De Oliveria et al. ${ }^{(23)} 2011$ and Kane et al. ${ }^{(26)} 2012$ reported QoR40 score outcomes. The analysis of overall RoQ40 score favored the ropivacaine group over the control group significantly [MD=17.68, 95\% CI: (1.48, 33.87); p<0.001]. Data were heterogeneous ( $\mathrm{p}=0.001, \mathrm{I}^{2}=85 \%$ ) (Figure 4A). Heterogeneity was best solved by employing the leave-one-out method to exclude De Oliveira et al. ${ }^{(23)} 2011$ (0.50\%) ( $\left.\mathrm{p}=0.56, \mathrm{I}^{2}=0 \%\right)$, and there was significant favoring of the ropivacaine group over the control group $[\mathrm{MD}=25.99,95 \% \mathrm{CI}$ : $(18.20,33.77)$; $\mathrm{p}<0.001$ ] (Figure 4B).

Detailed analysis for each item of the QoR-40 score (physical comfort, physical independence, emotional status, pain, and support) is shown in Figure 5; there was no significant difference between the two groups regarding each item of QoR-40.

\section{Opioid Rescue}

All studies reported opioid rescue outcomes. The analysis showed no significant difference between the groups [MD=2.57, 95\% CI: $(-6.62,1.49) ; \mathrm{p}=0.21]$. Data were heterogeneous $\left(\mathrm{p}<0.001, \mathrm{I}^{2}=79 \%\right)$ (Figure $\left.6 \mathrm{~A}\right)$. Heterogeneity was best solved using the leave-one-out method excluding De Oliveira et al. ${ }^{(23)}$ $2011(0.50 \% \mathrm{mg})\left(\mathrm{p}=0.18, \mathrm{I}^{2}=36 \%\right)$. The net result of the analysis showed no significant difference between the groups $[\mathrm{MD}=-0.31,95 \% \mathrm{CI}:(-3.00,-2.38) ; \mathrm{p}=0.82]$. Figure 6B shows the analysis of opioid rescue outcomes after the leave-one-out method.

\section{Discussion}

Our analysis found that the ropivacaine neither significantly reduce pain following laparoscopic hysterectomy nor opioid consumption in the first $24 \mathrm{~h}$. It significantly controlled overall RoQ40, but there was no difference between ropivacaine and

Table 1. Baseline characteristics of the included studies

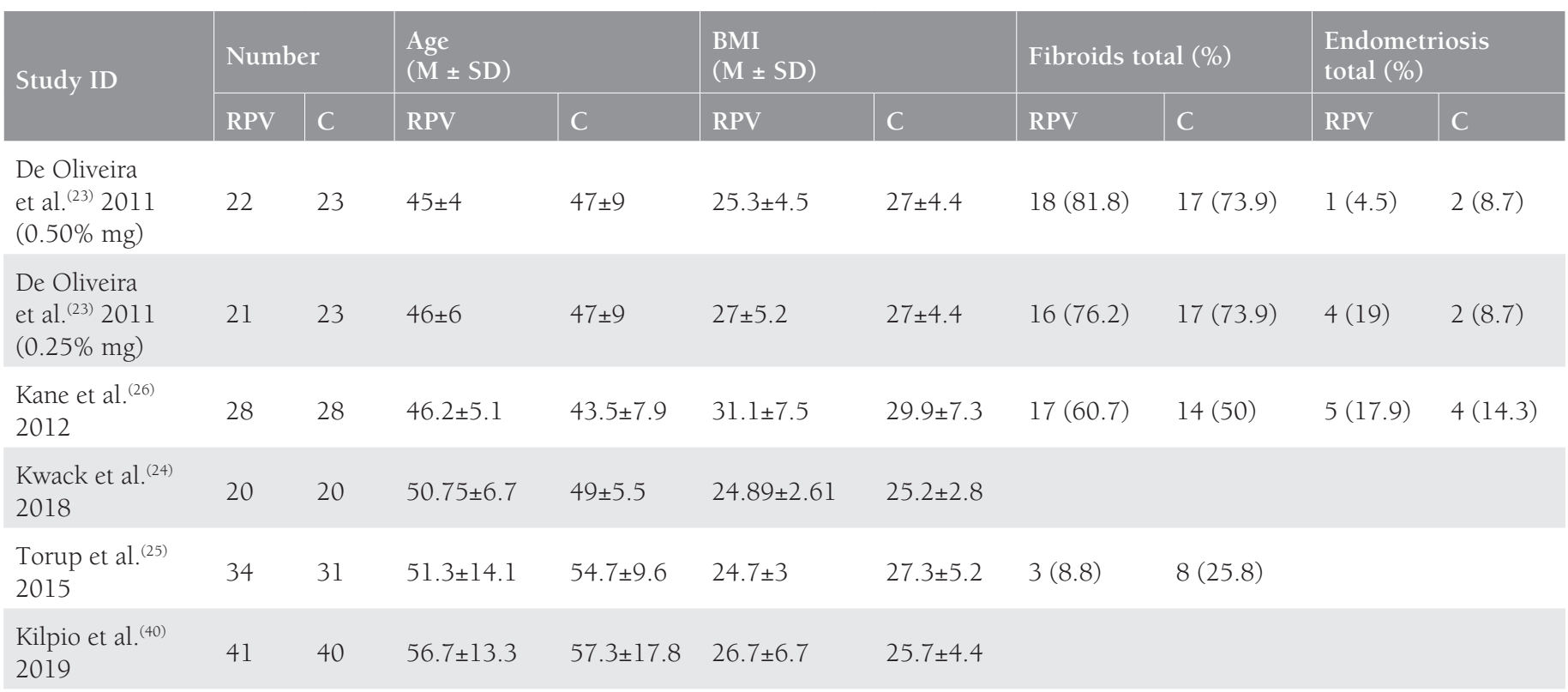

RPV: Ropivacaine, C: Control (placebo), M: Mean, SD: Standard deviation

Table 2. Surgery time and blood loss estimation in each of the included studies

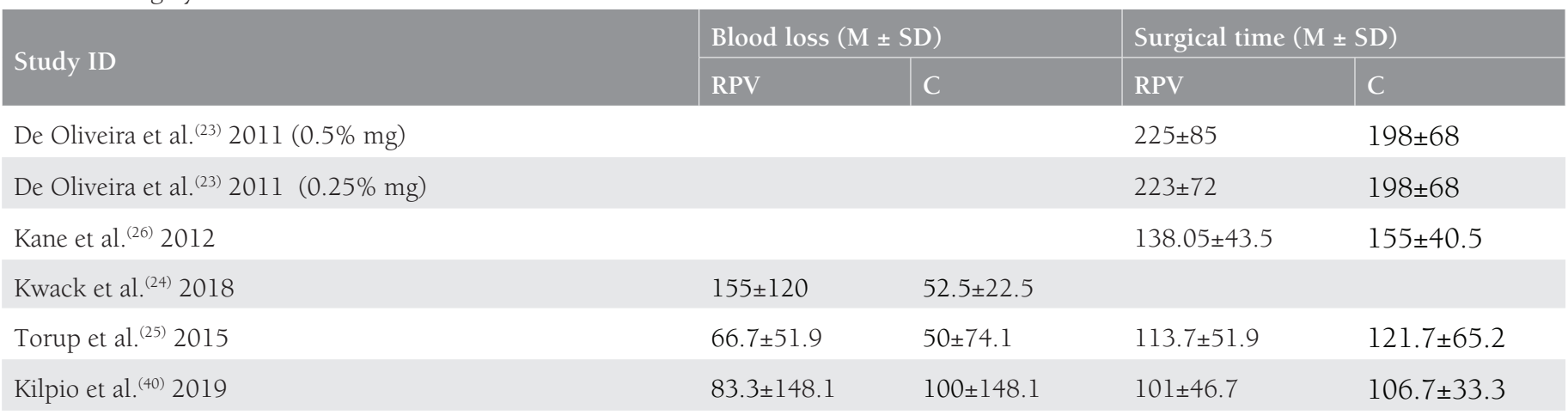

RPV: Ropivacaine, C: Control (placebo), M: mean, SD: Standard deviation 
placebo in control items of the QoR-40 score (physical comfort, physical independence, emotional status, pain, and support). Of the five included studies, three administered ropivacaine through (TAP) ${ }^{(23,25,26)}$, one through vaginal cuff infiltration ${ }^{(27)}$, and one simply administered it vaginally ${ }^{(24)}$. Kwack et al. ${ }^{(24)}$ assessed pain score at different hours during the entire 24
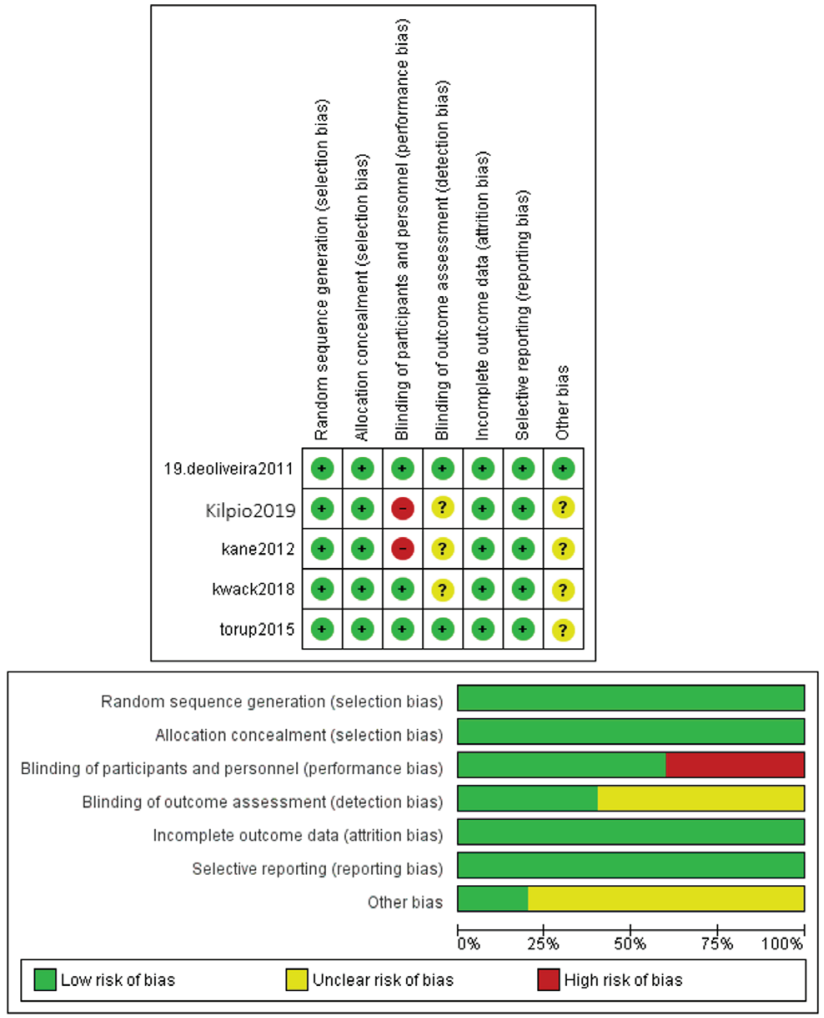

Figure 2. Risk of bias chart hours and found that ropivacaine was superior to placebo in reducing postoperative pain intensity only at $2 \mathrm{~h}$, but there was no significant difference in pain reduction at 6,12 , and 24 h. De Oliveira et al. ${ }^{(23)}$ compared two different concentrations of ropivacaine $(0.5 \%$ and $0.25 \%)$ with saline, concluding that there was no difference between the $0.25 \%$ ropivacaine group or the $0.5 \%$ ropivacaine group and the saline group in the reduction of postoperative opioid consumption ${ }^{(23)}$.

The use of the TAP block in most of our studies could explain why ropivacaine did not significantly control post-laparoscopic hysterectomy pain, which usually arises from the perineum, shoulder, and abdomen. Abdominal pain originates from somatic and visceral components with the visceral pain being stronger ${ }^{(28)}$. A TAP block potentially covers somatic pain only because it blocks sensory nerves in the thoracolumbar region that supply the anterolateral abdominal wall(29-31). Some authors theorized that for the reduction of postoperative pain, ropivacaine should be administered in such a way as to be absorbed systemically ${ }^{(32)}$. A review by Shin et al. ${ }^{(33)}$ demonstrated that TAP block was not significant in pain reduction and morphine consumption in the first $24 \mathrm{~h}$ following laparoscopic hysterectomy. Kwack et al. ${ }^{(24)}$ focused on control visceral pain through the injection of ropivacaine into the uterosacral area to block pelvic visceral plexus (uterine nerve plexus). They found that there was a reduction in early postoperative pain and the need for analgesics(33).

Acharya et al. ${ }^{(34)}$ and Chiruvella et al. ${ }^{(35)}$ concluded that adding dexmedetomidine to ropivacaine was effective in the management of postoperative pain and reduced analgesic consumption following laparoscopic hysterectomy. They also found that this combination was superior to using ropivacaine alone ${ }^{(34,35)}$. In comparison with lidocaine, Ghisi et al. ${ }^{(36)}$ found

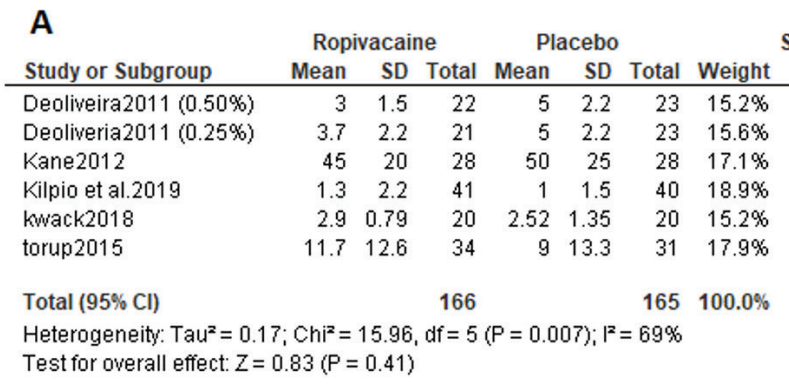

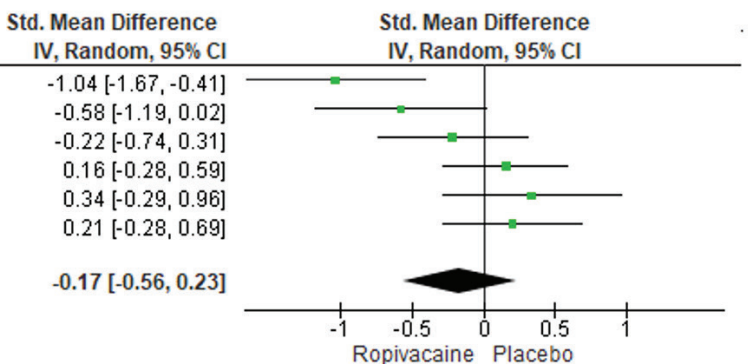

B

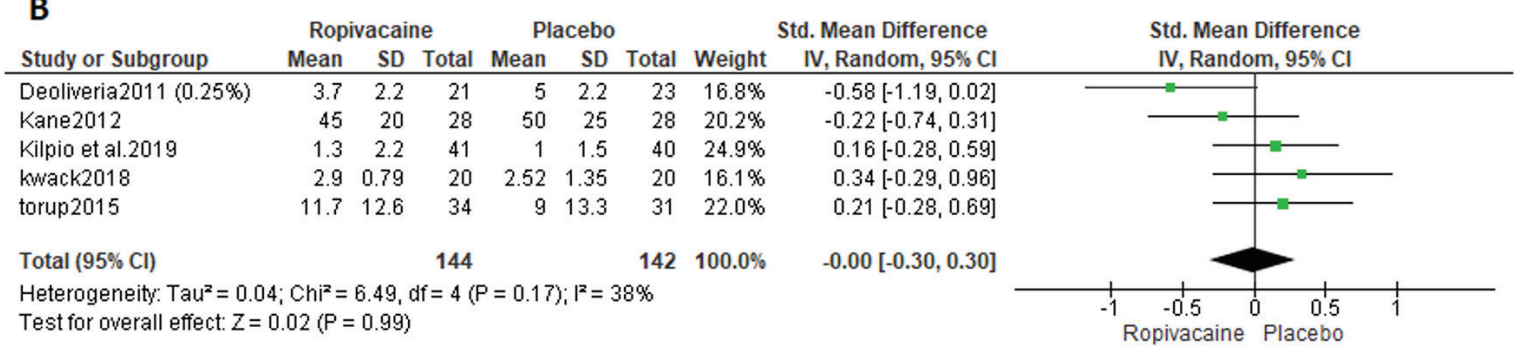

Figure 3. Postoperative pain in included studies

SD: Standard deviation, CI: Confidence interval 


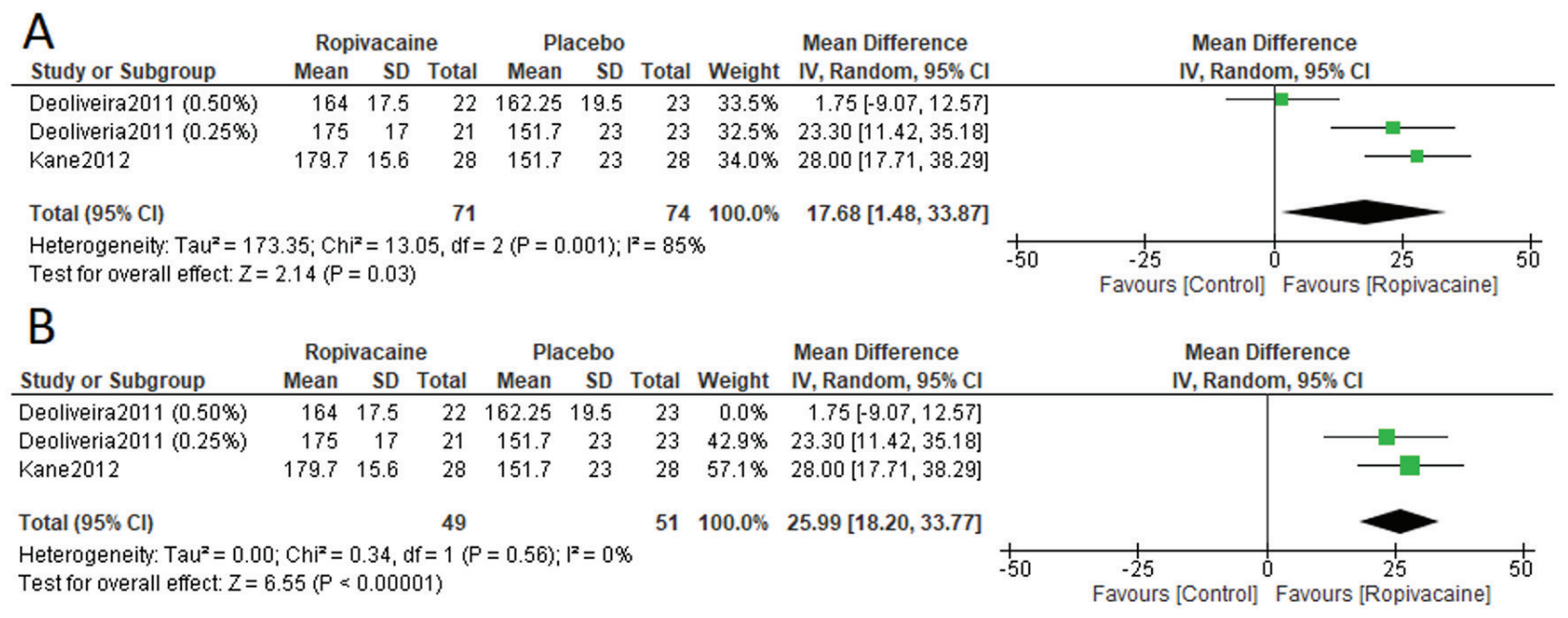

Figure 4. RoQ scores in included studies

SD: Standard deviation, CI: Confidence interval

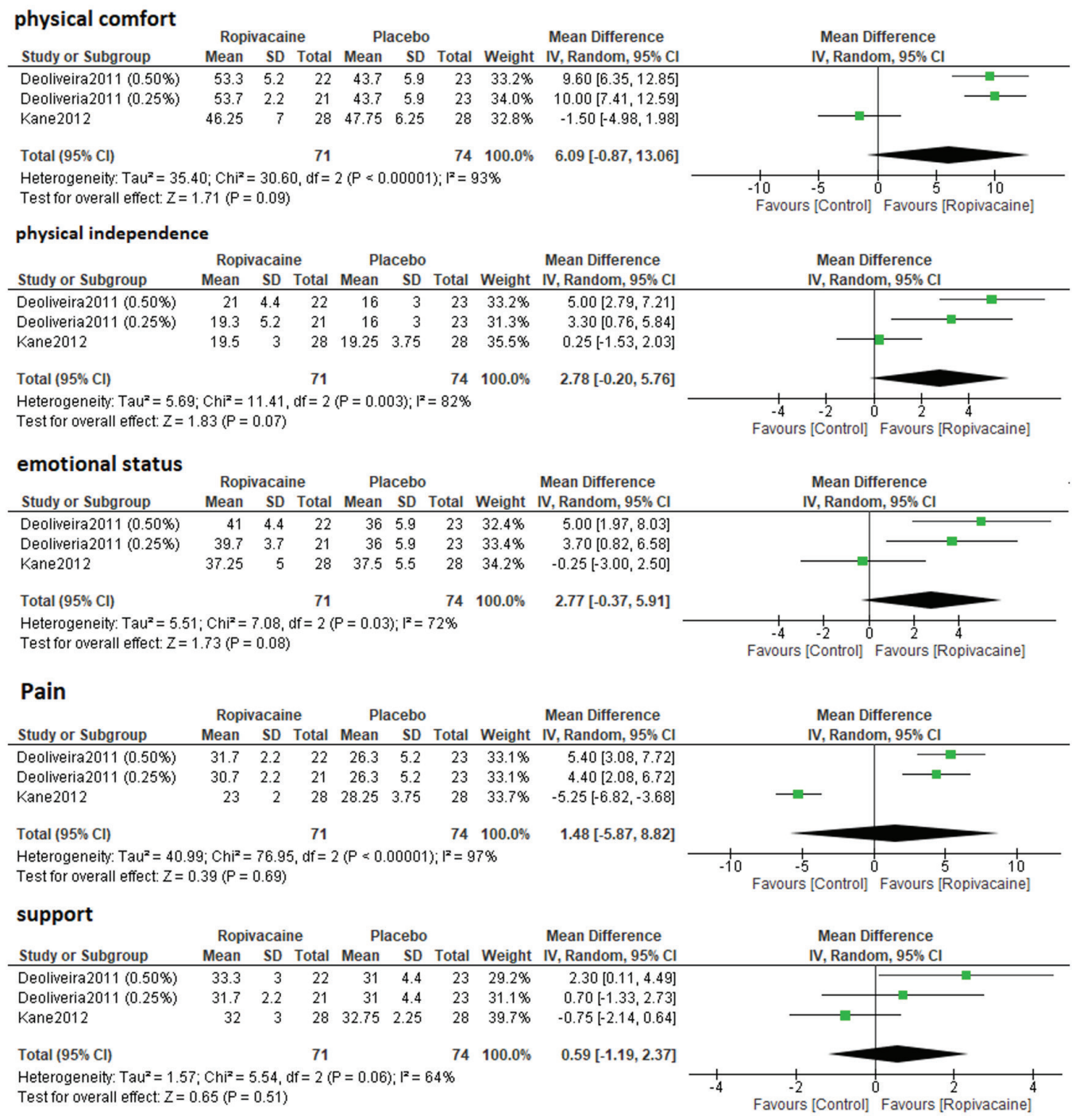

Figure 5. Components of RoQ scores

SD: Standard deviation, CI: Confidence interval 


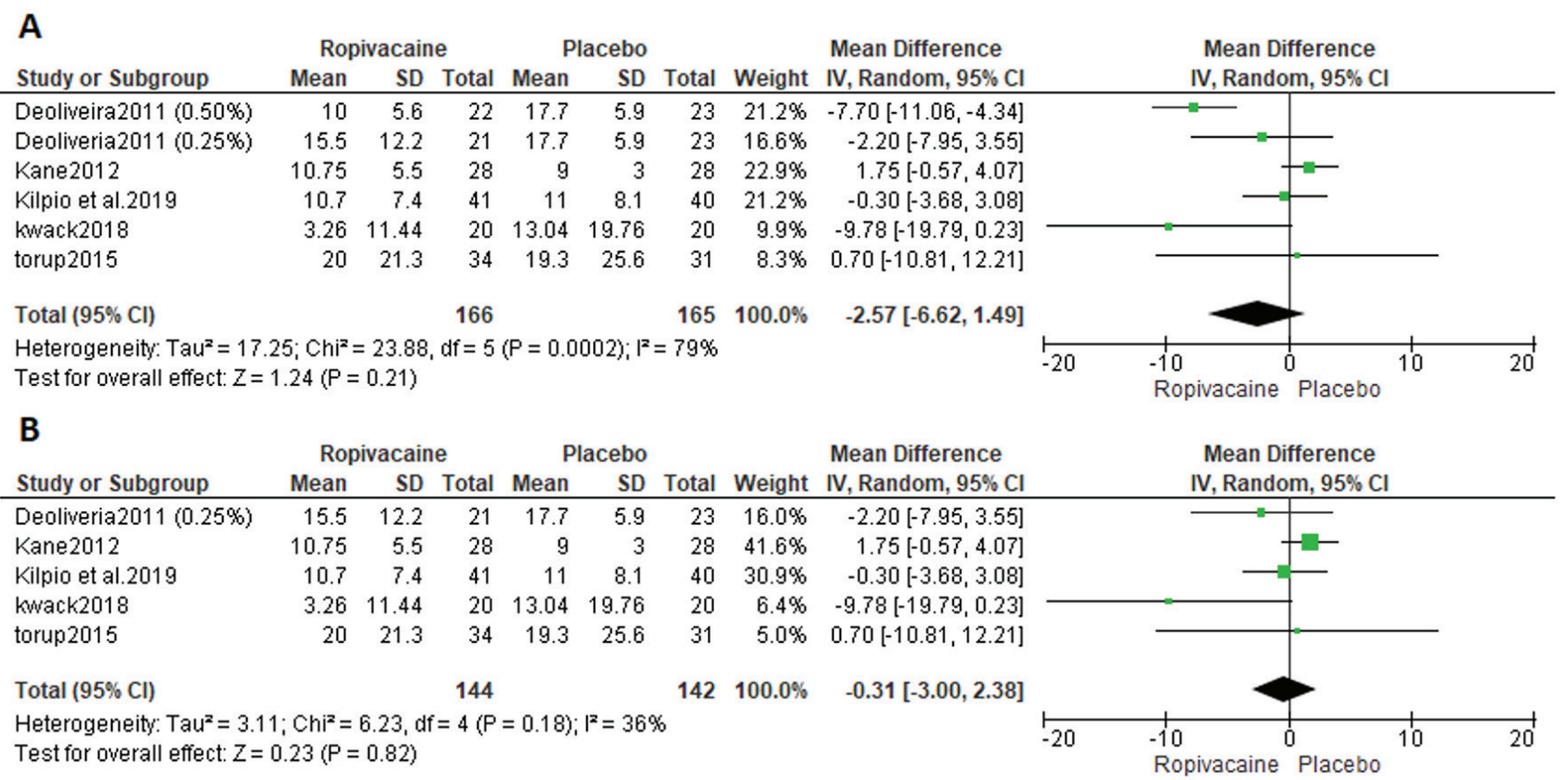

Figure 6. Incidence of use of opioid rescue

SD: Standard deviation, CI: Confidence interval

no difference in the analgesic effect of ropivacaine in pain control after laparoscopic abdominal surgeries, but the cost of lidocaine was lower than that of ropivacaine.

Chou et al. ${ }^{(28)}$ showed that the use of ropivacaine via the intraperitoneal route was effective in pain control and reduced analgesic consumption after laparoscopic appendectomy. Thakur et al. ${ }^{(37)}$ found that the ropivacaine significantly reduced postoperative pain and analgesic consumption following laparoscopic cholecystectomy through combined wound and intraperitoneal instillation. Likewise, Yong and Guang ${ }^{(38)}$ found that ropivacaine could reduce pain following laparoscopic cholecystectomy, but only when administered through an intraperitoneal installation ${ }^{(39)}$.

A RCT by Korkmaz et al. ${ }^{(39)}$ showed that bupivacaine could significantly reduce VAS scores and tramadol consumption after laparoscopic hysterectomy ${ }^{(40)}$. However, Chatrath et al. ${ }^{(41)}$ found that ropivacaine was better than bupivacaine in its analgesic effect with fewer adverse effects.

The main strength of our analysis was that it included only RCTs with low ROB. The main limitation of our study was the very low number of studies, the fact that we were forced to pool studies in which ropivacaine was injected as part of a TAP block along with those that administered or injected vaginal ropivacaine. More clinical trials are needed to investigate the efficacy of ropivacaine in pain relief after laparoscopic hysterectomy, and ultimately studies need to be performed to differentiate the efficacy and advantages of the different routes of administration. In conclusion, our analysis found that ropivacaine did not significantly reduce pain intensity and analgesic consumption after laparoscopic hysterectomy.
Acknowledgements: The Marchand Institute for Minimally Invasive Surgery would like to acknowledge the efforts of all of the students, researchers, residents and fellows at the institute who put their time and effort into these projects without compensation, only for the betterment of medicine. We firmly assure them that the future of medicine belongs to them.

\section{Ethics}

Peer-review: Externally and internally peer-reviewed.

\section{Authorship Contributions}

Surgical and Medical Practices: G.J.M., A.A., K.S., Concept: G.J.M., S.A., S.R., K.W., Design: A.K., K.C., A.S., J.L., Data Collection or Processing: S.H., Analysis or Interpretation: S.R., K.W., Literature Search: K.C., A.S., J.L., Writing: G.J.M., A.A., K.S., S.A., S.R., K.W., S.H., G.B., A.K., K.C., A.S., J.L.

Conflict of Interest: No conflict of interest was declared by the authors.

Financial Disclosure: The authors declared that this study received no financial support.

\section{References}

1. Jacobson GF, Shaber RE, Armstrong MA, Hung YY. Hysterectomy rates for benign indications. Obstet Gynecol 2006;107:1278-83.

2. Nieboer TE, Hendriks JC, Bongers MY, Vierhout ME, Kluivers KB. Quality of life after laparoscopic and abdominal hysterectomy: a randomized controlled trial. Obstet Gynecol 2012;119:85-91.

3. Garry R, Fountain J, Mason S, Hawe J, Napp V, Abbott J, et al. The eVALuate study: two parallel randomised trials, one comparing laparoscopic with abdominal hysterectomy, the other comparing laparoscopic with vaginal hysterectomy. BMJ 2004;328:129. 
4. Babalola EO, Bharucha AE, Melton LJ 3rd, Schleck CD, Zinsmeister AR, Klingele CJ, et al. Utilization of surgical procedures for pelvic organ prolapse: a population-based study in Olmsted County, Minnesota, 1965-2002. Int Urogynecol J Pelvic Floor Dysfunct 2008;19:1243-50.

5. Mouton WG, Bessell JR, Otten KT, Maddern GJ. Pain after laparoscopy. Surg Endosc 1999;13:445-8.

6. Gauta J. Outpatient laparoscopic hysterectomy: evaluation of pain. JSLS 2011;15:346-9.

7. Gibbison B, Kinsella SM. Postoperative analgesia for gynecological laparoscopy. Saudi J Anaesth 2009;3:70-6.

8. Lenz H, Sandvik L, Qvigstad E, Bjerkelund CE, Raeder J. A comparison of intravenous oxycodone and intravenous morphine in patient-controlled postoperative analgesia after laparoscopic hysterectomy. Anesth Analg 2009;109:1279-83.

9. Moore RA, McQuay HJ. Prevalence of opioid adverse events in chronic non-malignant pain: systematic review of randomised trials of oral opioids. Arthritis Res Ther 2005;7:1046-51.

10. Callesen T, Hjort D, Mogensen T, Schouenborg L, Nielsen D, Reventlid $\mathrm{H}$, et al. Combined field block and i.p. instillation of ropivacaine for pain management after laparoscopic sterilization. $\mathrm{Br}$ J Anaesth 1999;82:586-90.

11. Kuthiala G, Chaudhary G. Ropivacaine: A review of its pharmacology and clinical use. Indian J Anaesth 2011;55:104-10.

12. Cha SM, Kang H, Baek CW, Jung YH, Koo GH, Kim BG, et al.Peritrocal and intraperitoneal ropivacaine for laparoscopic cholecystectomy: a prospective, randomized, double-blind controlled trial. J Surg Res 2012;175:251-8.

13. Kucuk C, Kadiogullari N, Canoler O, Savli S. A placebo-controlled comparison of bupivacaine and ropivacaine instillation for preventing postoperative pain after laparoscopic cholecystectomy. Surg Today 2007;37:396-400.

14. Labaille T, Mazoit JX, Paqueron X, Franco D, Benhamou D. The clinical efficacy and pharmacokinetics of intraperitoneal ropivacaine for laparoscopic cholecystectomy. Anesth Analg 2002;94:100-5.

15. Abdallah FW, Chan VW, Brull R. Transversus abdominis plane block: a systematic review. Reg Anesth Pain Med 2012;37:193-209.

16. Johns N, O'Neill S, Ventham NT, Barron F, Brady RR, Daniel T. Clinical effectiveness of transversus abdominis plane (TAP) block in abdominal surgery: a systematic review and meta-analysis. Colorectal Dis 2012;14:635-42.

17. O'Donnell BD, McDonnell JG, McShane AJ. The transversus abdominis plane (TAP) block in open retropubic prostatectomy. Reg Anesth Pain Med 2006;31:91.

18. Hebbard P, Fujiwara Y, Shibata Y, Royse C. Ultrasound-guided transversus abdominis plane (TAP) block. Anaesth Intensive Care 2007;35:616-7.

19. Zafar N, Davies R, Greenslade GL, Dixon AR. The evolution of analgesia in an 'accelerated' recovery programme for resectional laparoscopic colorectal surgery with anastomosis. Colorectal Dis 2010;12:119-24.

20. Moher D, Liberati A, Tetzlaff J, Altman DG; PRISMA Group. Preferred reporting items for systematic reviews and meta-analyses: the PRISMA statement. PLoS Med 2009;6:e1000097.

21. Higgins JPT, Green S, Cochrane Collaboration, editors. Cochrane handbook for systematic reviews of interventions. Chichester, England ; Hoboken, NJ: Wiley-Blackwell; 2008. 649 p. (Cochrane book series).

22. Higgins JPT, Altman DG, Gøtzsche PC, Jüni P, Moher D, Oxman $\mathrm{AD}$, et al. Cochrane Bias Methods Group; Cochrane Statistical
Methods Group. The Cochrane Collaboration's tool for assessing risk of bias in randomised trials. BMJ 2011;343:5928.

23. De Oliveira GS Jr, Milad MP, Fitzgerald P, Rahmani R, McCarthy RJ. Transversus abdominis plane infiltration and quality of recovery after laparoscopic hysterectomy: a randomized controlled trial. Obstet Gynecol 2011;118:1230-7.

24. Kwack JY, Kwon YS. Immediate postoperative pain control with ropivacaine following laparoscopic-assisted vaginal hysterectomy: A randomized double-blind pilot study. Taiwan J Obstet Gynecol 2018;57:654-8

25. Torup H, Bøgeskov M, Hansen EG, Palle C, Rosenberg J, Mitchell AU, et al. Transversus abdominis plane (TAP) block after robotassisted laparoscopic hysterectomy: a randomised clinical trial. Acta Anaesthesiol Scand 2015;59:928-35.

26. Kane SM, Garcia-Tomas V, Alejandro-Rodriguez M, Astley B, Pollard RR. Randomized trial of transversus abdominis plane block at total laparoscopic hysterectomy: effect of regional analgesia on quality of recovery. Am J Obstet Gynecol 2012;207:419.

27. Trial RC. Clinics in Surgery Vaginal Cuff Infiltration with a Local Anesthetic for Postoperative Pain after Laparoscopic Hysterectomy: A. 2019;4(November 2014):4-8.

28. Choi JB, Kang K, Song MK, Seok S, Kim YH, Kim JE. Pain Characteristics after Total Laparoscopic Hysterectomy. Int J Med Sci 2016;13:562-8.

29. El-Dawlatly AA, Turkistani A, Kettner SC, Machata AM, Delvi $\mathrm{MB}$, Thallaj A, et al. Ultrasound-guided transversus abdominis plane block: description of a new technique and comparison with conventional systemic analgesia during laparoscopic cholecystectomy. Br J Anaest 2009;102:763-7.

30. Chin KJ. Does low-volume inter-scalene block attenuate the severity of diaphragmatic paresis? Br J Anaesth 2009;102:142-3.

31. Abdallah FW, Laffey JG, Halpern SH, Brull R. Duration of analgesic effectiveness after the posterior and lateral transversus abdominis plane block techniques for transverse lower abdominal incisions: a meta-analysis. Br J Anaesth 2013;111:721-35.

32. Koppert W, Weigand M, Neumann F, Sittl R, Schuettler J, Schmelz $\mathrm{M}$, et al. Perioperative intravenous lidocaine has preventive effects on postoperative pain and morphine consumption after major abdominal surgery. Anesth Analg 2004;98:1050-5.

33. Shin JH, Balk EM, Gritsenko K, Wang A, Plewniak K, Shaparin N. Transversus Abdominis Plane Block for Laparoscopic Hysterectomy Pain: A Meta-Analysis. JSLS 2020;24:2020.00018.

34. Acharya R, Karan D, Khetan M. Postoperative Analgesia With Intraperitoneal Ropivacaine With and Without Dexmedetomidine After Total Laparoscopic Hysterectomy: a Randomized, DoubleBlind, Controlled Trial. Asian J Pharm Clin Res 2016;9:76.

35. Chiruvella S, Nallam S. Intraperitoneal instillation of ropivacaine plus dexmedetomidine for pain relief after laparoscopic hysterectomy: A comparison with ropivacaine alone. J Dr NTR Univ Health Sci 2016;5:93-7.

36. Ghisi D, Fanelli A, Jouguelet-Lacoste J, La Colla L, Auroux AS, Chelly JE. Lidocaine versus ropivacaine for postoperative continuous paravertebral nerve blocks in patients undergoing laparoscopic bowel surgery: a randomized, controlled, double-blinded, pilot study. Local Reg Anesth 2015;8:71-7.

37. Thakur MK, Singh KR, Singh LJ, Singh CAK. Use of combined wound and intraperitoneal ropivacaine instillation in laparoscopic cholecystectomy for postoperative pain management: A prospective randomized study at a referral center in Northeast India. JMS - J Med Soc 2019;33:16-9. 
38. Yong L, Guang B. Intraperitoneal ropivacaine instillation versus no intraperitoneal ropivacaine instillation for laparoscopic cholecystectomy: A systematic review and meta-analysis. Int J Surg 2017:44:229-43.

39. Korkmaz Toker M, Altiparmak B, Uysal Aİ, Demirbilek SG. The analgesic efficacy of oblique subcostal transversus abdominis plane block after laparoscopic hysterectomy: A randomized, controlled, observer-blinded study. Medicine (Baltimore) 2019;98:e13994.
40. Kilpio O, Härkki P, Mentula M, Pakarinen PI. Vaginal Cuff Infiltration with a Local Anesthetic for Postoperative Pain after Laparoscopic Hystertomy: A randomized control trial. Clinics of Surgery 2019;4:1-5.

41. Chatrath C, Khetarpal R, Kumari H, Kaur H. Inter-incisor gap, modified Mallampati grade horizontal length of the mandible, head and neck movements, sternomental distance, and TMD. Anesth Essays Res 2018;12:349-54. 